\title{
THE CRUSTACEAN COMMUNITIES OF RIVER TAGUS RESERVOIRS. ZOOPLANKTON STRUCTURE AS RESERVOIR TROPHIC STATE INDICATOR
}

\author{
Maria-José Caramujo and Maria-José Boavida' \\ Dept. Zoologia and Centro de Biologia Ambiental, Faculdade de Ciências, Univ. Lisboa \\ Campo Grande C2. 1749-016Lisboa. Portugal. zboavida@fc.ul.pt \\ 1- To whom correspondence should be addressed.
}

\begin{abstract}
Ten reservoirs of the Tagus River Basin were studied during three years to assess their trophic state. Seasonal abundance of zooplankton was followed. Species composition and food web structure were analysed to relate abundance and proportion of certain species or groups of species to reservoir trophic state. Low zooplankton concentration and high water transparency values were associated with high ratio of calanoids to cyclopoids and the presence of large Daphnia populations. High Acanthocyclops robustus density was associated with large populations of Bosmina in the most eutrophic reservoirs.
\end{abstract}

Key words: Copidadiaptomus numidicus, Thermocyclops dybowskii, Acanthocyclops robustus, Calanoid-Cyclopoid interactions, zooplankton, crustaceans, reservoirs, trophic state index, seasonal dynamics.

\section{RESUMEN}

Durante tres años se ha estudiado los cambios estacionales en la abundancia del zooplancton de diez embalses de In cuenca del río Tagus con la finalidad de establecer su estado trófico. Para ello se ha estudiado la composición de especies y la estructura de la cadena trófica. Los resultados obtenidos han permitido relacionar la abundancin de ciertas especies o grupos de especies con el estado trófico de los embalses. Así, la buja concentracidn de zooplancton y la elevada transparencia del ugua están asociados a un cociente calanoides/ciclópidos elevado y a la presencia de grandes poblaciones de Daphnia. Igualmente, en los embalses más eutróficos, una grun densidad de Acanthocyclops robustus se asocia a una gran abundancia de Bosmina.

Palabras clave: Copidadiaptomus numidicus, Thermocyclops dybowskii, Acanthocyclops robustus, Calanoid-Cyclopoid inteructions, zooplancton, crustáceos, embulses, índice de estado trófico, dinámica estacional.

\section{INTRODUCTION}

In Tagus River Basin as well as in the Iberian Peninsula, lakes are virtually unexistent and reservoirs are the most important water bodies (Armengol, 1980). The studied reservoirs are located in distinct areas and are subjected to different climatological and anthropogenic influences. These influences along with different age result in different reservoir trophic state. The seasonallity and nature of zooplankton assemblages may constitute important sources of information to assess reservoir trophic state.
The ratio of calanoid to cyclopoid copepods frequently declines with eutrophication (Gannon \& Stemberger, 1978; Hurlbert \& Mulla, 1981; Gulati, 1984; Muck \& Lampert, 1984; Maier, 1996; Adrian, 1997). Considering the possible interactions between cyclopoids and calanoids, competition is probably dominant among naupliar stages while among copepodid stages competition, predation and cannibalism may be all influential (Soto \& Hurlbert, 1991a). Calanoid nauplii have been referred to endure starvation more adequately than cyclopoid nauplii (Soto \& Hurlbert, 1991a, b) and both cala-

L.imnética 18:37.56 (2000)

() Asociación Española de Limnología. Madrid. Spain 


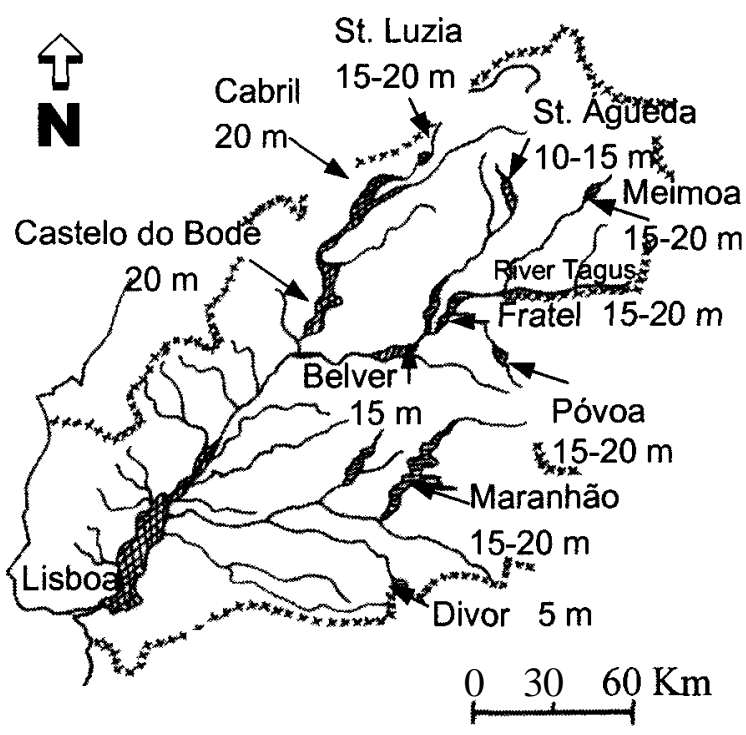

Figure 1. Reservoir location, and depth of sampling tows. Situacidn de los embalses $v$ profundidad de las pescas verticales.

noid nauplii and adults have lower food threshold concentrations than cyclopoids (Santer, 1994; Hansen \& Santer, 1995). The abundance of predaceous cyclopoid adults is thus dependent on the survival of herbivorous developmental stages competing with calanoids for edible phytoplankton. Furthermore, when food is scarce, calanoids may reduce phytoplankton availability to rotifers and indirectly reduce cyclopoid prey (Soto \& Hurlbert, 1991b). Rotifer species composition and abundance have been considered good indicators of water quality (Gannon \& Stemberger, 1978; Pejler, 1983; Karabin, 1985) and Matveeva (1991) considered that the trophic state of a lake may be reflected on the total summer rotifer density.

Our purpose is to investigate the organization and seasonality of zooplankton assemblages during a three year seasonal survey in 10 reservoirs located in the Tagus River Basin. The geographical distribution of species is compared with previous references for Spain (Armengol, 1978, 1980, Margalef et al., 1976, Toja, 1980). Considering that the abundance pattern of species and the food web structure may be altered by eutro- phication (Schindler 1987; Carpenter et al. 1993) part of this study was directed to the relationship between the crustacean type of community and the trophic state of the reservoir. Comparisons with literature are discussed.

\section{MATERIAL AND METHODS}

\section{Reservoirs and Environmental data}

The reservoirs sampled are located in the Tagus River Basin (Fig. 1). Three of the reservoirs, St. Luzia, Cabril and Castelo do Bode (C. Bode) are an example of chain reservoirs on Zêzere River. These reservoirs, along with Meimoa and St. Agueda (or Marateca) are located at the North side of Tagus River and Divor, Maranhão and Póvoa are located on the southern side. Fratel and Belver are two reservoirs resulting from dams on Tagus River.

Except for Divor, Belver and Fratel, all reservoirs are warm monomictic with stable thermal stratification from May-June until the end of September. In 1994 and 1995 thermal stratification was in progress after mid-April due to higher air temperatures in the first months of these years relatively to 1993 (Fig. 2). The warmest year was 1995 with an annual average of $16.2^{\circ} \mathrm{C}$ and the highest monthly average temperatures with an exception for September (Meteorological Institute, Portugal). Divor is a shallow reservoir (maximum depth $8 \mathrm{~m}$ ) in an open landscape. In Divor the weak thermal gradient is easily broken by the wind and in Belver and Fratel thermal stratification can only be established in periods of small river flow.

The reservoirs north to the river Tagus are characterised by soft waters, being the minimum value of $18.5 \mathrm{mg} \mathrm{CO}_{3}{ }^{2-} / 1$ recorded for Meimoa Reservoir in the summer of 1995 and the maximum of $33.8 \mathrm{mg} \mathrm{CO}_{3}{ }^{2-} / 1$ for $\mathrm{C}$. Bode in the summer of 1994. The reservoirs located on Tagus River had soft to moderately soft waters (40 to $\left.120 \mathrm{mg} \mathrm{CO}_{3}{ }^{2-} / 1\right)$ and the three reservoirs south to Tagus had hard waters (minimum of $158.5 \mathrm{mg}$ $\mathrm{CO}_{3}^{2-/} 1$ for Maranhiio). 

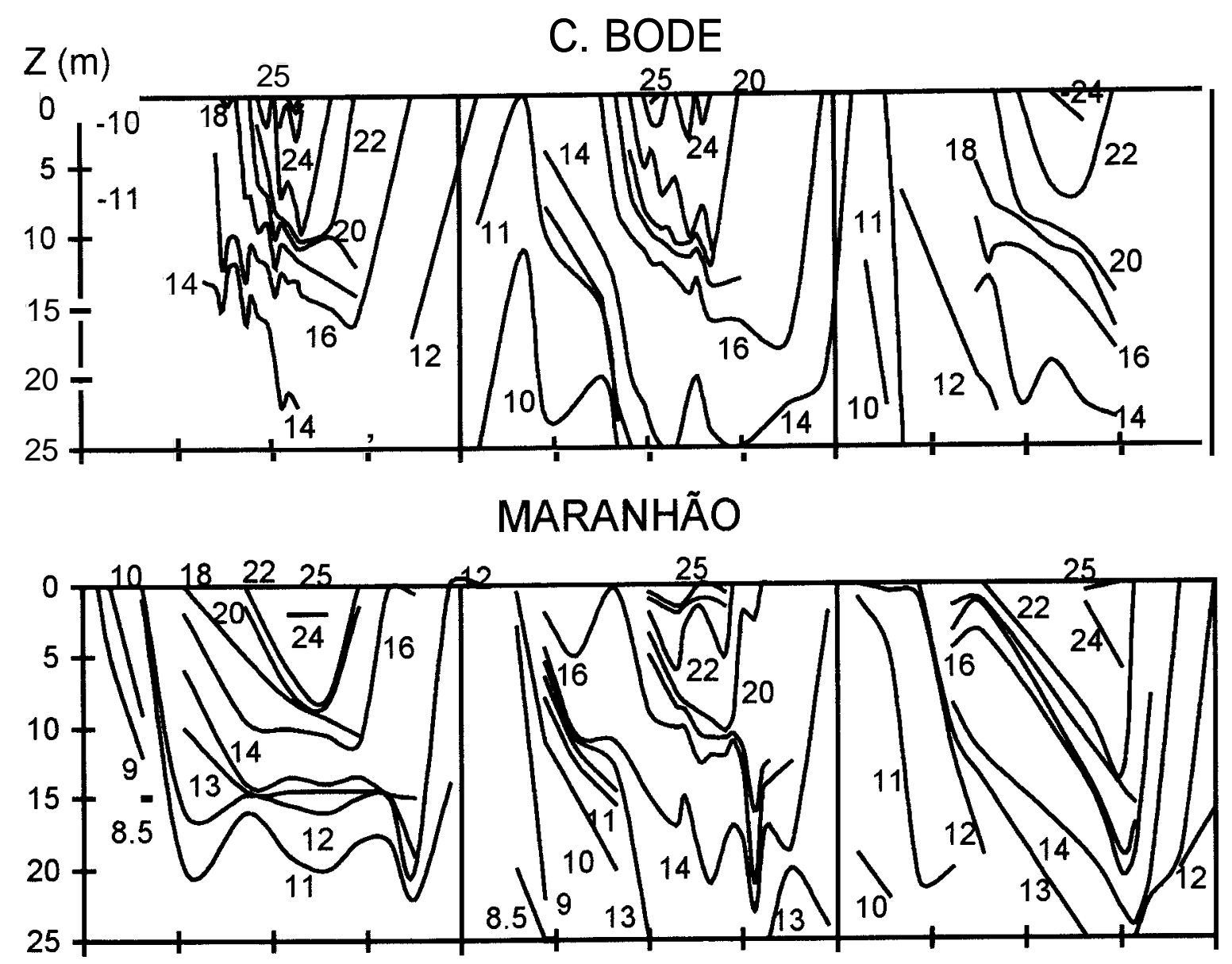

DIVOR

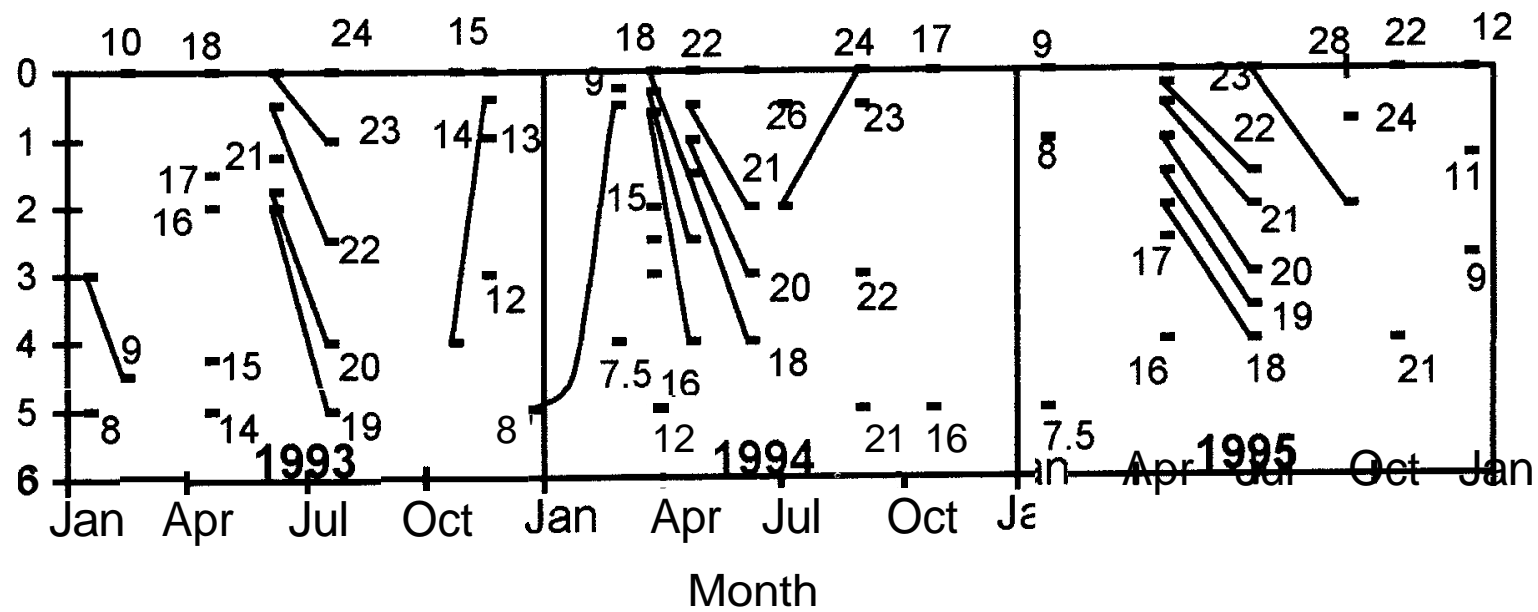

Figure 2. Thermal stratification in deep reservoirs to the North of Tagus River (C. Bode), South of the Tagus River (Maranhão) and in a shallow reservoir (Divor). Estratificación térmica en los embalses profundos al Norte del río Tagus (C. Bode), al Sur (Maranhão) y en un embalse somero (Divor). 
Transparency values were usually high during winter and low at the beginning of summer. Exceptions occurred when the sampling date was preceded by short periods of rainfall, such as during the winter of 1993 when silt was washed to the reservoirs. The highest transparency values where measured at S. Luzia, Cabril, C. Bode and Meimoa reservoirs. However, the seasonal values for Meimoa decreased gradually after the summer of 1994. The lowest transparency values were recorded for the reservoirs south to Tagus River and Agueda Reservoir. All reservoirs showed a tendency for eutrophication during 1994. The lack of rain and higher air temperatures accounted for a general decrease in the water level of the reservoirs, excluding Belver and Fratel. Years 1993, 1994 and 1995 were dry and the reservoirs exhibited the minimum water level in the summer of 1995 (Meteorological Institute, Portugal). The situation was particularly acute in the reservoirs south to Tagus River and was altered only after October 1995.

\section{Sampling}

On each sampling date, two vertical hauls ( $20 \mathrm{~m}$ long or maximum reservoir depth) were taken with a Wisconsin type net of $80 \mu \mathrm{m}$ mesh size at a central sampling station. Samples were taken in December or January (winter), March (spring), July or August (summer) and October (autumn) during 1993, 1994 and 1995. In order to record the depth distribution of each crustacean population during summer, samples were collected with van Dorn bottles at $2 \mathrm{~m}$ intervals. Average chlorophyll-a (CHLa) concentrations were calculated from samples taken at $2 \mathrm{~m}$ intervals from surface until $15 \mathrm{~m}$ depth or maximum reservoir depth. CHLa was extracted in acetone. Animals were anaesthetised with carbonated water and preserved in sugar saturated formaldehyde $(2 \% \mathrm{v} / \mathrm{v})$. Copepodid stage five and adult copepods (C V and C VI, respectively) and all stages of Cyclops spp. and Macrocyclops albidus were counted in the whole samples from vertical hauls, whereas copepodid stages one to four (C I to C IV) and nauplii of each species were counted in subsam- ples. When the density of cladocerans was high, two subsamples of $1 / 5$ of the total volume were analysed and rotifers were counted in subsamples of $1 / 10$ or $1 / 20$ of the total sample volume. Since rotifers were collected with a net of $80 \mu \mathrm{m}$ mesh size, when a finer mesh is appropriate $(25-50 \mu \mathrm{m}$ mesh size, Nogrady, 1993), all rotifer densities should be considered with caution. Some of the Daphnia species, henceforth referred as Daphnia hyalina, belong to the Daphnia hyalina-galeata complex (Flossner \& Kraus, 1986) or were later identified as $D$. longispina or close to $D$. galeatu (Schwenk et al., 1998). Copepods were identified according to Kiefer (1978) and Dussart \& Fernando (1990).

\section{Numerical procedures, indices and statistics}

All calculations were based on two replicate samples from each reservoir. The method applied to estimate water hardness followed Standard Methods (1992) and values were scaled according to Sawyer (1960 in Standard Methods, 1992). In order to relate zooplankton assemblages to reservoir trophic state, Karabin (1985) index was applied to total summer rotifer density and the ratio of calanoids to cyclopoids was calculated. To estimate the relative proportion of crustacean

Table 1. Classification of crustacean species according to nature and mode of food collection (see text for references). Clasificación de los crustáceos de acuerdo con su estrategia alimentaria(veuseel texto para las referencias).

\begin{tabular}{|c|c|}
\hline COPEPODS & CLADOCERANS \\
\hline $\begin{array}{l}\text { I. CARNIVOROUS } \\
\text { Acanthocyclops robustus } \\
\text { Cyclops strennus } \\
\text { Cyclops vicinus } \\
\text { Macrocyclops albidus }\end{array}$ & $\begin{array}{l}\text { IV. MICROFILTERS } \\
\text { Diaphanosoma brachyurum } \\
\text { Ceriodaphnia sp. } \\
\text { Bosmina longirostris }\end{array}$ \\
\hline $\begin{array}{l}\text { III. HERBIVOROUS } \\
\text { NON-FILTRATING } \\
\text { Thermocyclops dybowskii } \\
\text { Tropocyclops prasinus }\end{array}$ & $\begin{array}{l}\text { V. MACROFILTERS } \\
\text { Daphnia pulex } \\
\text { Daphnia hyalina x galeata } \\
\text { Daphnia parvula } \\
\text { Daphnia cuccullata }\end{array}$ \\
\hline
\end{tabular}


groups with particular feeding requirements to total crustacean population, species were grouped according to the nature and collection of food as classified by Margalef (1953), Fryer (1957), Brooks and Dodson (1965) and Hutchinson (1967) (Table 1).

Spearman's correlation coefficient was used to measure the degree of association: (i) among reservoirs using chlorophyll-a (CHLa) values; (ii) between rotifer densities and CHLa; (iii) between rotifer densities and proportion of crustacean classes; (iv) between the proportion of classes II to IV and CHLa; (v) among proportion of classes II to $\mathrm{V}$, also considering the proportion of class I to be constant and (vi) between clutch size (CLS) of Acanthocyclops robustus and CHLa. Secchi disk transparency values were regressed on CHLa values to investigate the dependence of reservoir transparency on the amount of CHLa. Appropriate probability values were adjusted for the number of simultaneous tests according to the sequential Bonferroni technique (Rice, 1989).

Carlson's (1977) trophic state index (TSI) was applied to chlorophyll (CHLa) values using the formula:

$\operatorname{TSI}(\mathrm{CHLa})=10^{*}\left(6-\frac{2.04-0.68 \ln (\mathrm{CHLa})}{\ln 2}\right)$

TSI applied to Secchi disk transparency data was not calculated since reservoirs received, periodically, high amounts of non-algal particulate organic matter (pers. obs.). Moreover, in some reservoirs turbidity of the water may be controlled by light absorbing compounds other than chlorophyll (Caramujo \& Boavida, 1998).

Cluster analysis was performed on the full data set of crustacean taxa abundances comprising each season sets in the total number of reservoirs, using the Manhattan dissimilarity measure and Ward's sum of squares clustering algorithm. The same method of cluster analysis was applied to CHLa concentration, density of A. robustus and species abundance. Data were $\log 10(n+1)$ transformed prior to analyses. The STATISTICA pattern analyses package (I 995) was used.

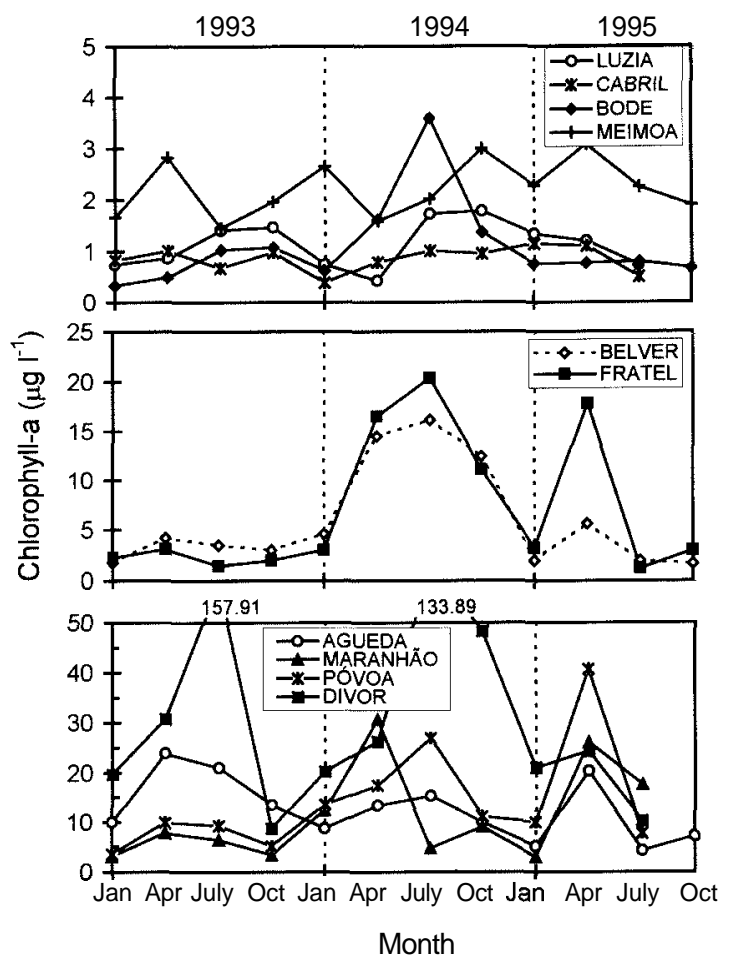

Figure 3. Average Chlorophyll-a values in reservoirs with transparency values higher than $4 \mathrm{~m}$ (St. Luzia, Cabril, C. Bode Meimoa); transparency values between 2 and $4 \mathrm{~m}$ (Belver, Fratel) and in reservoirs with transparency values lower than $2 \mathrm{~m}$ (St. Agueda, Maranhão, Póvoa, Divor). Media de las concentraciones de clorofila a en embalses con transparencias mayores a $4 \mathrm{~m}$ (St. Luzia, Cabril, C. Bode); tansparencias entre 2 y $4 \mathrm{~m}$ (Belver, Fratel) y en embalses con transparencias menores a $2 \mathrm{~m}$ (St. Águeda, Maranhiio, Povoa, Divor).

\section{RESULTS}

\section{Chlorophyll}

For the year of 1993 most reservoirs with average transparency values below $2 \mathrm{~m}$ showed maxima in chlorophyll-a (CHLa) average values during spring (Fig. 3). In 1994, except for Maranhão reservoir, high values of CHLa were registered mainly during the summer when blooms of algae developed. Diatom blooms were observed in S. Luzia, Cabril, C. Bode and Meimoa and blooms of Aphanizomenon flos-aquae and Microcystis aeroginosa were observed in the other reservoirs. 
Table 2. Trophic state index (TSI, from CHLa values) of the reservoirs belonging to the Tagus River system. Indices de estado trófico (TSI según las concentruciones de clorofila) de los embalses pertenecientes al sistema del río Tagus.

\begin{tabular}{llll} 
Reservoir & $\mathbf{1 9 9 3}$ & $\mathbf{1 9 9 4}$ & $\mathbf{1 9 9 5}$ \\
\hline Belver & Mesotrophic & Meso-Eutrophic & Mesotrophic \\
Cabril & Oligotrophic & Oligotrophic & Oligotrophic \\
C. Bode & Oligotrophic & Mesotrophic & Oligotrophic \\
Divor & Eutrophic & Eutrophic & Meso-Eutrophic \\
Fratel & Mesotrophic & Eutrophic & Meso-Eutrophic \\
Maranhão & Meso-Eutrophic & Meso-Eutrophic & Mesotrophic \\
Meimoa & Mesotrophic & Mesotrophic & Mesotrophic \\
Póvoa & Meso-Eutrophic & Meso-Eutrophic & Eutrophic \\
St. Agueda & Eutrophic & Meso-Eutrophic & Mesotrophic \\
St. Luzia & Oligotrophic & Oligotrophic & Oligotrophic \\
\hline
\end{tabular}

In 1995 CHLa values peaked in spring and the species which formed blooms in previous summers were observed in small quantities with the exception of Meimoa. The seasonal fluctuations in CHLa values were not correlated among reservoirs (highest $\mathrm{r}=0.590$ for $\mathrm{C}$. Bode $\mathrm{x}$ Divor; d.f. $=11 ; \mathrm{p}=0.057$ ) and transparency values were not dependent on CHLa values (highest adjusted $\mathrm{r}^{2}=0.153$ for $\mathrm{C}$. Bode with $\mathrm{F}_{1,10}=2.99, \mathrm{p}=$ 0.12 ). CHLa was generally in higher concentrations at 5 to $10 \mathrm{~m}$ depth in the clear water reservoirs and at 3 to $5 \mathrm{~m}$ depth in more turbid reservoirs (transparency values of less than $2 \mathrm{~m}$ ).

Carlson's trophic state index (TSI) calculated from summer CHLa values allowed the classification of Cabril and St. Luzia as oligotrophic reservoirs and C. Bode as mesotrophic in 1993 and 1994 and oligotrophic in 1995 (Table 2). All other reservoirs were either mesotrophic or eutrophic.

\section{Zooplankton Abundance Patterns}

The largest zooplankton densities were recorded in the southern reservoirs. Maximum was recorded in Divor where densities over 1000 ind./l were observed during the summers. Minima abundances were observed in St. Luzia, Cabril, C. Bode and Meimoa reservoirs.

\section{Rotifers}

In all reservoirs rotifer maxima were recorded during summer. St. Luzia had the lowest rotifer density (minimum of 88 individuals $/ \mathrm{m}^{3}$ ) and the highest values were recorded in Divor and Póvoa $\left(613 \times 10^{3}\right.$ and $352 \times 10^{3}$ ind. $/ \mathrm{m}^{3}$, respectively). Rotifer summer density indicated Divor as a mesotrophic reservoir (Fig. 4). Both in Póvoa and Divor reservoirs, rotifera abundances were correlated to CHLa (lowest value for Divor with $\mathrm{r}=$ $0.738 ;$ d.f. $=8 ; \mathrm{p}=0.04)$.

\section{Cladocerans}

Daphnia and Diaphanosoma dominated the cladoceran community in reservoirs of larger transparency values (more oligotrophic) while Bosmina dominated in the other reservoirs (Fig. 5). Both Daphnia hyalina and Diaphanosoma bra-

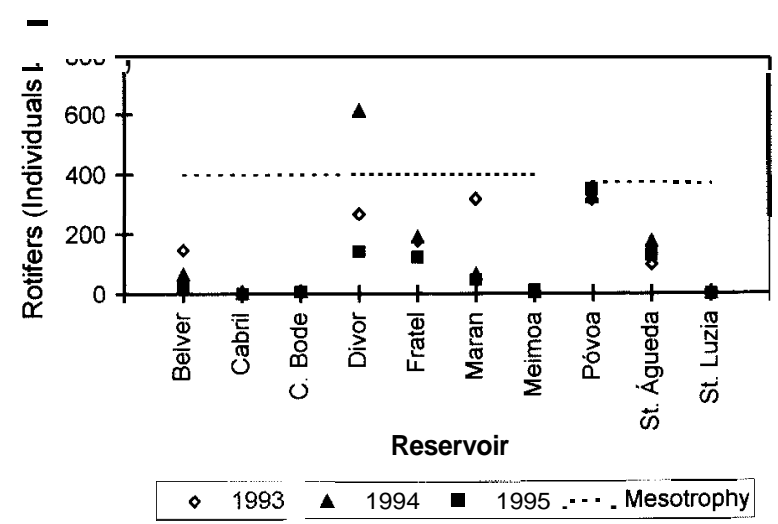

Figure 4. Summer rotifer densities during the sampling years Values above $400 \mathrm{ind} / \mathrm{l}$ indicate mesotrophy (Karabin, 1985) Densidad de rotíferos en veruno durente los años muestreados Valores supertores a 400 ind 


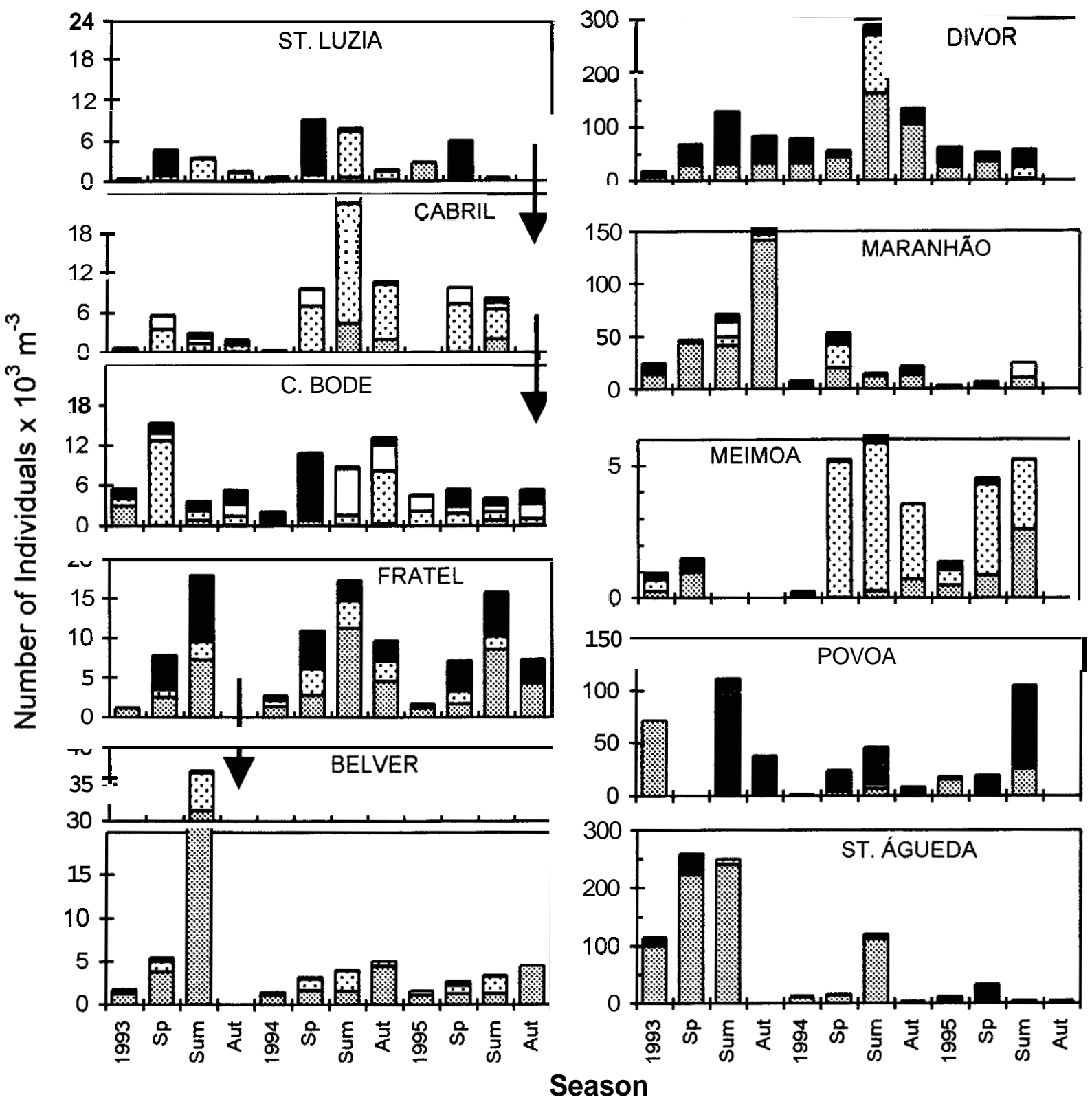

\section{@ Bosmina @ Ceriodaphnia 口Diaphanosoma Daphnia}

Figure 5. Seasonal cladoceran densities in each reservoir. Winter from each year is represented by the year cardinal number, spring as "Sp", summer as "Sum" and autumn as "Aut". Arrows indicate water flow direction in chain reservoirs. Densidades estacionales de cladóceros en cada embalse. El invierno se representa por el número del año, primavera como "Sp", verano como "Sum" y otoño como "Aut". Las flechas indican la dirección del agua en la cadena de embalses. 


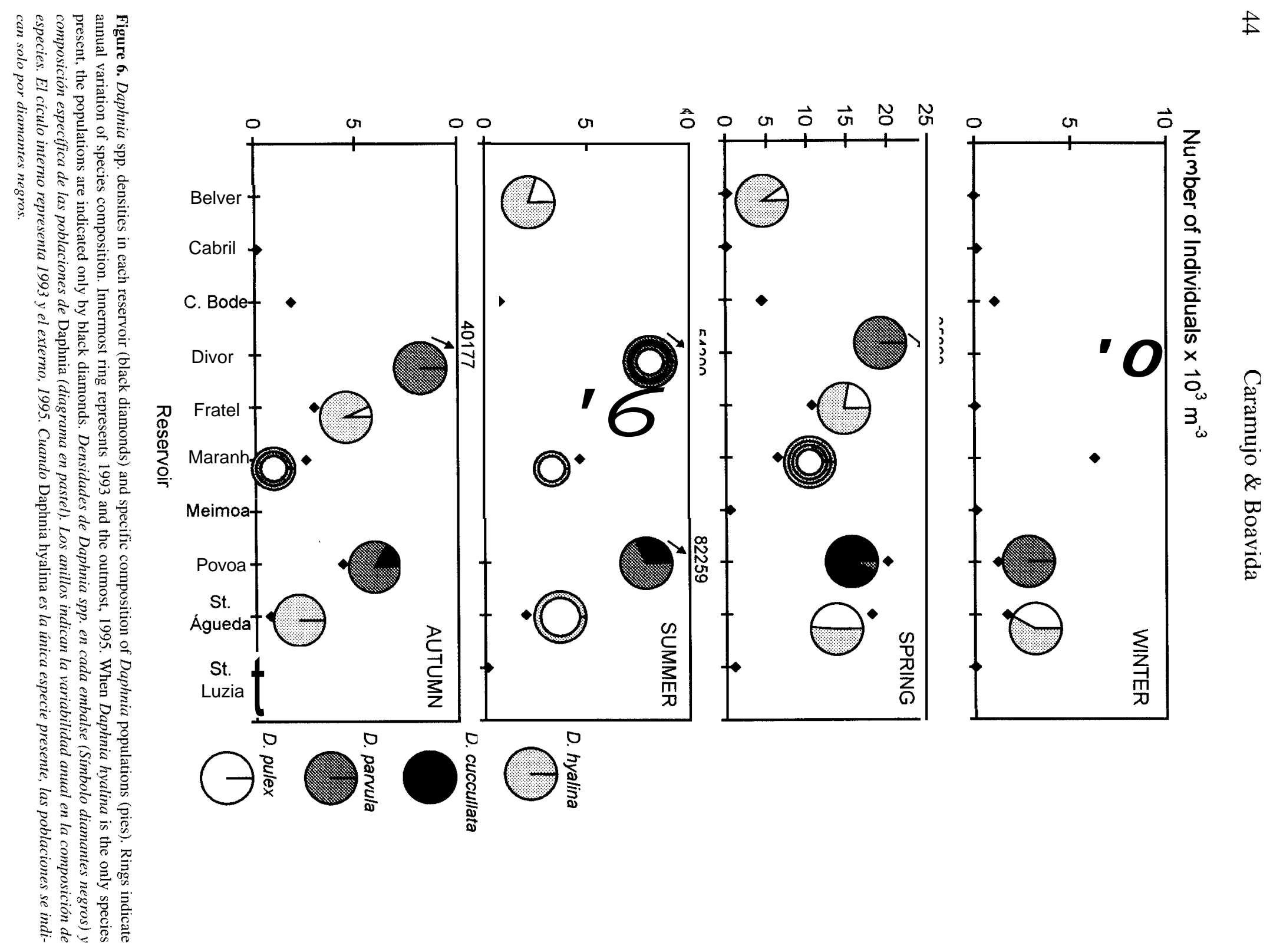


chyurum were not observed in Divor and Povoa reservoirs, and Diaphanosoma was absent from Meimoa reservoir. Daphnia hyalina exhibited larger populations during spring while Diaphanosoma had larger summer populations. In Maranhão, the inverse relationship between Daphnia and Diaphanosoma abundances reached a maximum when Daphnia disappeared altogether during the summers of 1994 and 1995 only to recover in autumn of 199.5. Divor and Maranhão reservoirs presented seasonal and annual differences in Daphnia species composition. D. pawula was present in Maranhão during the spring of 1993, being replaced during summer by D. hyalina, and was the dominating Daphnia species in autumn of the same year (Fig. 6). In Divor the largest population of Daphnia belonged to the species D. pawula and in the winter of 1993 D. cucullata was represented by a small population. In the summer of $1994, D$. cucullata was represented by a large, dominating population that disappeared afterwards. In Póvoa D. pawula and D. cucullata alternated according to the season. D. pawula was the only species present during the winter while D. cucullata was clearly dominating during spring and was subsequently replaced by $D$. parvula during summer and autumn.

D. pulex was present in Agueda, Belver and Fratel reservoirs (Fig. 6). The largest populations were recorded in Agueda during winter and spring. In autumn, small populations of $D$. hyalina were present. During the summer, both Daphnia populations were suppressed in St. Agueda in 1993 and 1994, while in 199.5 a small population of D. hyalina was present. In Belver and Fratel D. pulex started to develop in spring and increased in numbers during the summer, followed, in Fratel, by D. hyalina population that dominated in autumn (Fig. 6).

\section{Copepods}

A total of 9 copepod species was recorded for the reservoirs of Tagus River Basin during the 3 year survey (Table 3).

Copidodiaptomus numidicus dominated the communities where transparency values were larger, usually accompanied by Daphnia (either from hyalina $\times$ galeata group or pulex group) and Ceriodaphnia sp. (Fig. 7). C. numidicus was absent in Póvoa, Meimoa and Divor and was represented by low number of individuals in Fra-

Table 3. Species of copepods present in the reservoirs of Tagus River Basin. Reservoirs are indicated by the first two letters of their names. Copepod species that occurred only occasionally are marked with an asterisk $\left(^{*}\right)$. Especies de copépodos presentes en los embalses de la cuenca del río Tagus. Los embulses se indicun por las dos primeras letras de su nomhre. Las especies de copépodos que solo uparecen ocasionalmente estan marcudo con un usterisco (*).

\begin{tabular}{|c|c|c|c|c|c|c|c|c|c|c|}
\hline Copepoda & Ág & $\mathrm{Be}$ & $\mathrm{Ca}$ & Bo & Div & Fra & Ma & $\mathrm{Me}$ & Pó & $\mathrm{Lu}$ \\
\hline \multicolumn{11}{|l|}{ Calanoida } \\
\hline Copidodiaptornus numidicus & + & + & + & + & & + & + & & & + \\
\hline \multicolumn{11}{|l|}{ Cyclopoida } \\
\hline Acanthocyclops robustus & + & + & + & + & + & + & + & + & + & + \\
\hline Cyclops strenuus & & & + & + & & & & & & \\
\hline Cyclops vicinus & & + & & & & + & & & & \\
\hline Macrocyclops albidus & & & & & & & & + & & + \\
\hline Thermocyclops dybowskii & & + & + & + & & + & + & & & + \\
\hline Tropocyclops prasinus & & & & & & & & + & & \\
\hline Paracyclops fimbriatus * & & + & & & & + & & & & \\
\hline Eucyclops serrulatus * & & + & & & & & & & & \\
\hline \multicolumn{11}{|l|}{ Harpacticoida } \\
\hline Canthocamptus sp. ${ }^{*}$ & & & & + & & & & & & \\
\hline
\end{tabular}



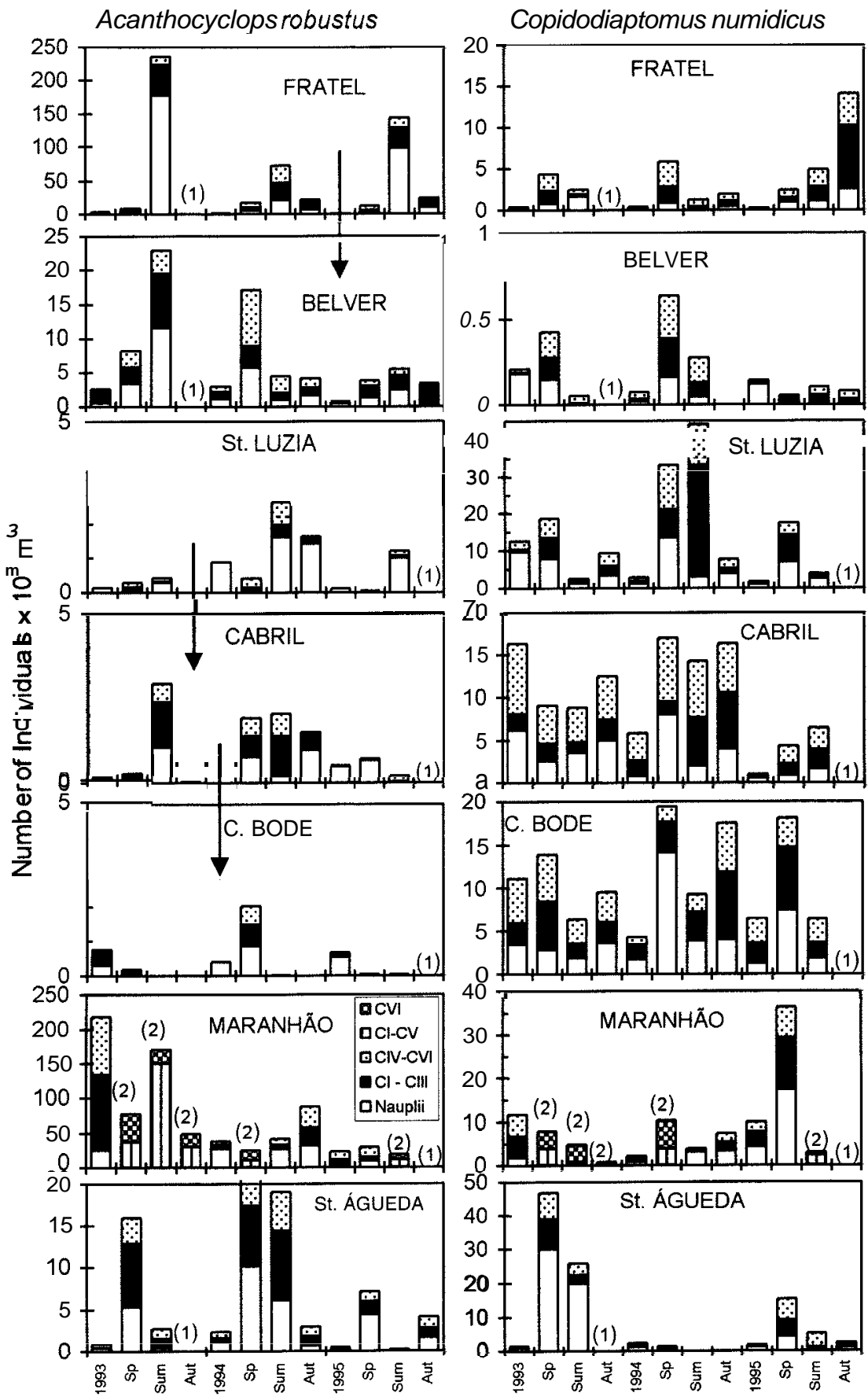

Season

$\square$ Nauplii $\square \mathrm{Cl}$ - CIII @CIV-CVI

Figure 7. Densities of main copepod populations in reservoirs where the calanoid C. numidicus was recorded. See legend of figure 5 for further details. Densidades de las principales poblaciones de copépodos en embalses donde se capturó el calanoide C. numidicus. (Ver leyenda de la figura 5 para más detalles). 


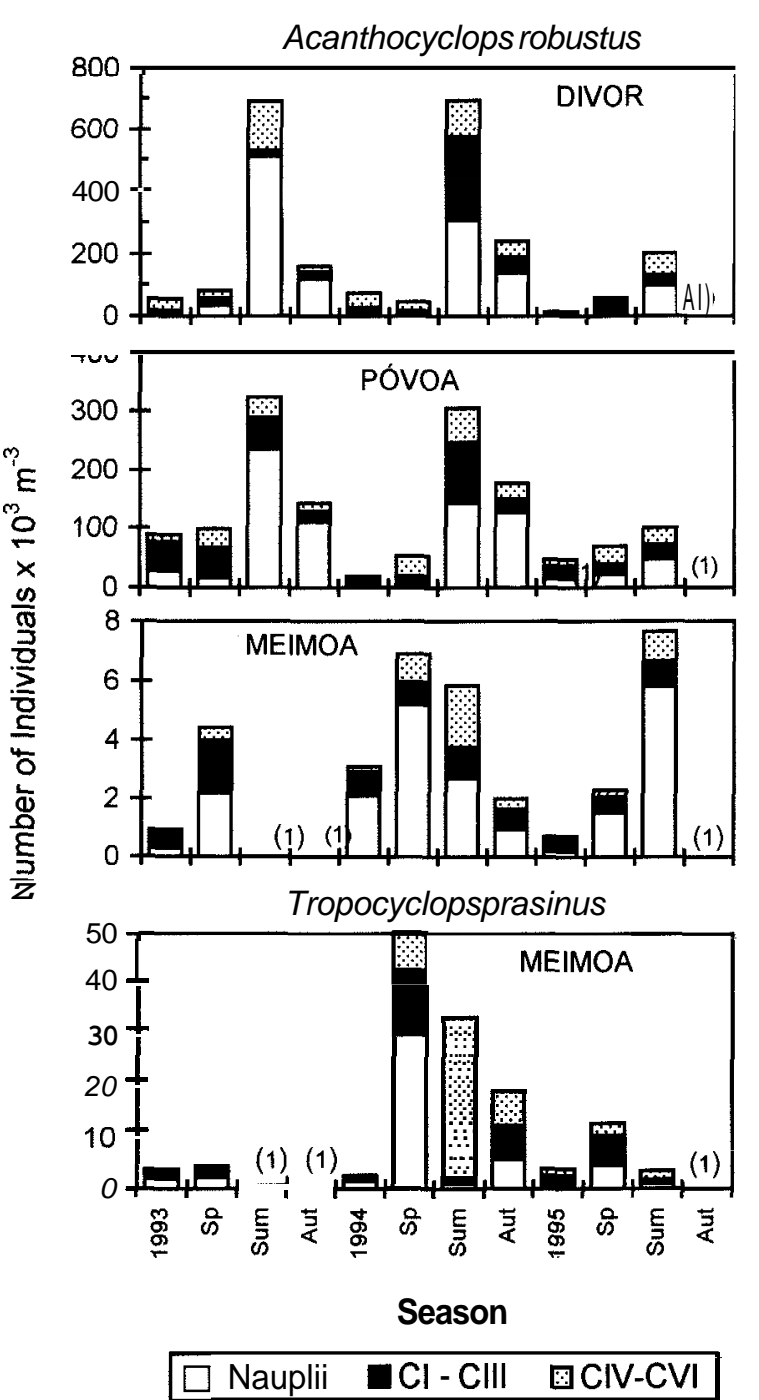

Figure 8. Cyclopoid densities in reservoirs without calanoid populations. Densidades de ciclopidos en embalses sin poblaciones de calanoides.

tel and Belver (Fig. 7). Thermocyclops dybowskii occurred mainly during the warmest seasons and during the winter was absent or represented mainly by adults and nauplii. 7: dybowskii never co-occurred with Tropocyclops prasinus (Meimoa reservoir) and was never observed in Águeda, Divor and Póvoa reservoirs. A. robustus was the dominant copepod in the zooplankton communities of the most eutrophic reservoirs. Population peaks were observed during spring or sum- mer (Fig. 7 and 8). In the reservoirs of lower CHLa concentration A. robustus almost disappeared during the coolest months. Considering A. robustus abundances at all seasons, three groups of reservoirs were obtained (Fig. 9): reservoirs (i) with A. robustus at low densities (Meimoa, St. Luzia, Cabril and C. Bode); (ii) with A. robustus intermediate densities (Agueda, Belver and Fratel) and (iii) with high densities of the cyclopoid (Divor, Póvoa and Maranhão). Macrocyclops albidus was present in St. Luzia and Meimoa. The largest population was recorded in Meimoa where 1390 ind $/ \mathrm{m}^{3}$ where found in spring. During the winter, only earlier nauplii and later copepodid stages could be observed. The populations always peaked during spring and autumn. Cyclops strenuus was observed in small numbers in C. Bode and Cabril and Cyclops vicinus was sporadically observed in Fratel and Belver.

Copepodid stages of the calanoid C. numidicus exceeded cyclopoid copepodid stages in reservoirs with higher transparency (Fig. 10). A decrease in the proportion of calanoids to cyclopoids was observed in summer samples when 7: dybowskii was present in the reservoirs. The proportion of calanoid nauplii to cyclopoid nauplii was lower than the relation evidenced by copepodid stages.

Relatively to the vertical distribution of species during the summers, only in Cabril reservoir a clear decrease in mean population depth of Daphnia and later copepodid stages of all cope-

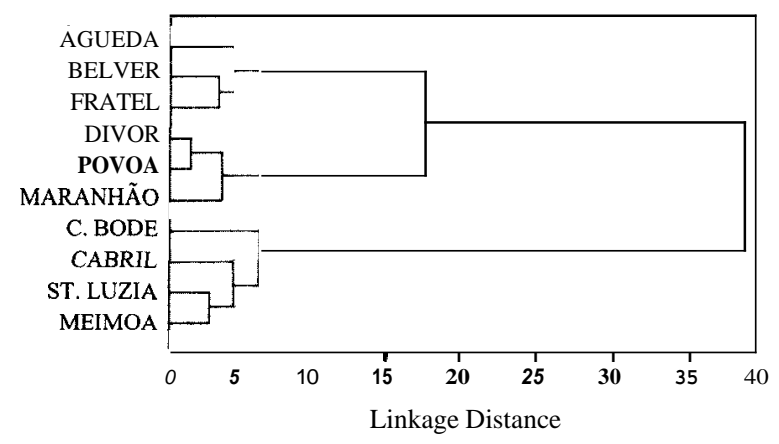

Figure 9. Dendrogram depicting groups of reservoirs according to A. robustus densities at all seasons. Dendrogruma mostrando los grupos de embalses según las densidades de A. robustus en todas las estaciones. 
pod populations during summer was observed (except for nauplii, only $10 \%$ of total zooplankton in the upper $10 \mathrm{~m}$ ). Later copepodid stages of T. dybowskii were always observed below $10 \mathrm{~m}$ and this vertical distribution was particularly clear in Maranhiio where $90 \%$ of all copepodid stages could be found between 8 and $20 \mathrm{~m}$ in summer samples. All other species were observed to dwell in the first $10 \mathrm{~m}$ of the reservoirs with occasional population peaks between 5 and $7 \mathrm{~m}$ depth. In shallow reservoirs and reservoirs without thermal stratification the populations had a roughly even distribution among depths.

\section{Zooplankton communities}

In order to reveal the structure of zooplankton communities the various crustacean species were grouped according to Table 1 . We have therefore distinguished carnivores from herbivores and, within this last class, copepods were separated from cladocerans. Carnivorous copepods dominated in the more eutrophic reservoirs and herbivorous copepods dominated the communities of the least eutrophic reservoirs (Fig. 11). Microfiltering cladocerans generally dominated over macrofilter cladocerans in more eutrophic reservoirs. However, population peaks for the latter were recorded during spring.
Except for St. Luzia, none of the classes varied with CHLa in a significant way. In St. Luzia the abundance of class IV was significantly correlated to CHLa ( $\mathrm{r}=0.742 ;$ d.f.= $11 ; \mathrm{p}<0.05)$ although this significance disappeared when the predator density (class I) was held constant $(\mathrm{r}=$ 0.417 ; d.f. $=8 ; \mathrm{p}>0.05)$. The importance of predators is further emphasized when the pair of classes II and IV and the pair of classes IV and V were only significantly correlated at constant predator density. In C. Bode and Cabril cyclopoid predators had a reduced influence on the other zooplankton classes (Table 4) although the significant correlation between classes II and IV was lost when predator density was controlled. In Maranhiio reservoir the abundance of class I was inversely correlated to the abundance of class 11 . In Belver, Fratel and Agueda a similar trend was recorded.

In Divor, rotifer abundances were correlated to class $\mathrm{V}$ abundances although that correlation became non-significant at constant predator-copepod densities (Table 4). Copepod predators were significantly correlated to class IV and the relation between macrofiltering and microfiltering cladocerans was only disclosed when the abundance of predator copepods was controlled. A. robustus CLS was correlated to $\mathrm{CHLa}(\mathrm{r}=0.757$; d.f. $=7 ; \mathrm{p}=0.05$ ) and this correlation was further

Table 4. Spearman's correlation coefficients and partial correlation coefficients between trophic classes of crustaceans in the reservoirs. * indicates significant $\mathrm{p} \leq 0.008$ adjusted for the number of simultaneous tests according to the sequential Bonferroni technique (Rice, 1989). (see Table 1 for information on trophic classes). Coeficientes de correlacidn de Spearman y de correlucidn parcial entre grupos trdfcos de crustáceos. *indica significativa para p $\leq 0.008$ ajustado al número de tests simultaneos de acuerdo con la técnica secuencial de Bonjerroni (Rice, 1989). (ver Tabla I pura informacidn sobre grupos trdfcos de crustaceos).

\begin{tabular}{lcc} 
& Sperman's correlation coefficient. df $=\mathbf{1 1}$ & Control for Group I. df $=\mathbf{8}$ \\
\hline $\begin{array}{l}\text { St. Luzia } \\
\text { Classes II x IV }\end{array}$ & -0.583 & $-0.945^{*}$ \\
\hline C. Bode & $-0.946^{*}$ & $-0.904^{*}$ \\
Classes II x III & & \\
\hline Maranhão & $-0.886^{*}$ & -0.747 \\
Classes I x II & & \\
\hline Divor & $-0.833^{*}$ & -1.000 \\
Rotifera x Class V & $-0.891^{*}$ & \\
Classes I x IV & 0.236 & \\
Classes IV x V &
\end{tabular}


enhanced when the total amount of eggs in the population (i.e. CLS $\times$ Ovigerous Females, $r=$ $0.984 ; \mathrm{df}=7 ; \mathrm{p}<0.01)$ was considered.

Considering the zooplankton classes I, II, III, $\mathrm{IV}$ and $\mathrm{V}$ at all seasons, three groups of reservoirs were obtained: (i) Cabril, C. Bode and St. Luzia; (ii) Belver, Fratel, Maranhão, Meimoa and St. Agueda and (iii) Divor and Póvoa, in which the dominant copepod groups were respectively (i) herbivores/detritivores; (ii) carnivores/detritivores and (iii) carnivores. The variation of species densities at each season allowed grouping of the reservoirs (Fig. 12). In winter two main groups were formed. Within the first group, Fratel, Maranhão and st. Agueda were farther from Cabril, C. Bode and St. Luzia. Meimoa was the reservoir at a greatest distance from all the others. In spring, Meimoa was grouped with Cabril, C. Bode and St. Luzia. A distinct second group was formed by Belver, Cabril (1994), C. Bode (1994), Fratel, Maranhão and St. Agueda. Divor and Póvoa made a separate group. In summer, Divor and Póvoa remained closely linked. The other reservoirs were not clearly grouped although Cabril and C. Bode showed a higher connection and Meimoa was placed at a greater distance from these reservoirs. In autumn, Divor and Póvoa remained at a low distance from each other and Cabril, C. Bode, St. Luzia and Meimoa formed a group distinct from Belver, Fratel, Maranhão, Meimoa (1994) and St. Agueda.

\section{DISCUSSION}

The classification of reservoirs according to TSI calculated from CHLa data allowed grouping of the reservoirs as (i) mainly oligotrophic: Cabril, C. Bode and St. Luzia; (ii) mesotrophic: Meimoa; (iii) Mesotrophic to Eutrophic: Belver, Fratel, Maranhão and St. Agueda and (iv) mainly eutrophic: Divor and Póvoa. In 1994, a general increase in CHLa, and in rotifera and cladoceran populations could be observed in the reservoirs.

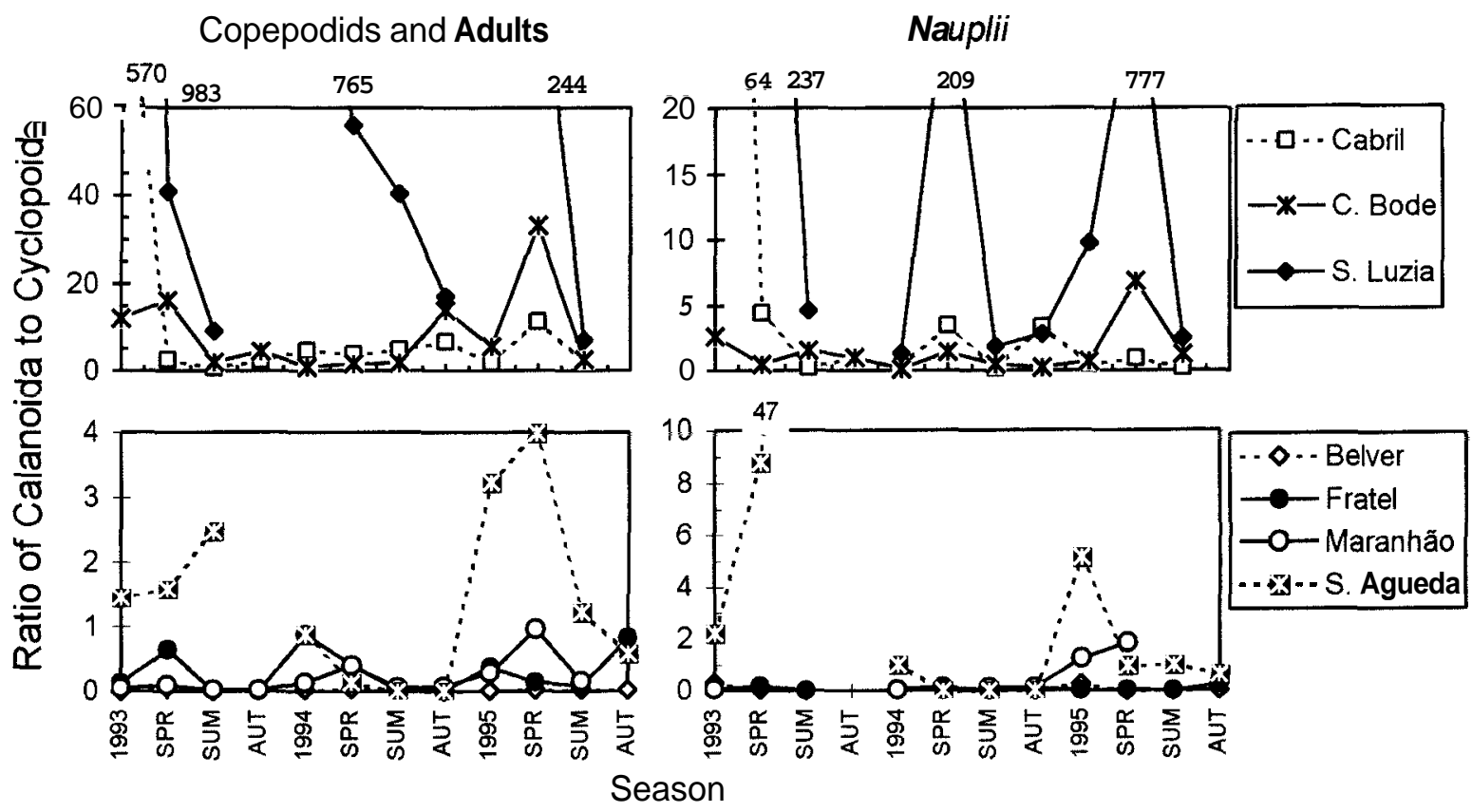

Figure 10. Ratio of calanoids to cyclopoids estimated for the reservoirs at each season. Note the different scales on YY axes. Relación de calanoides a ciclópidos rstimada para cada estación y embalse. Observe que hay diferentes escalas del eje Y. 


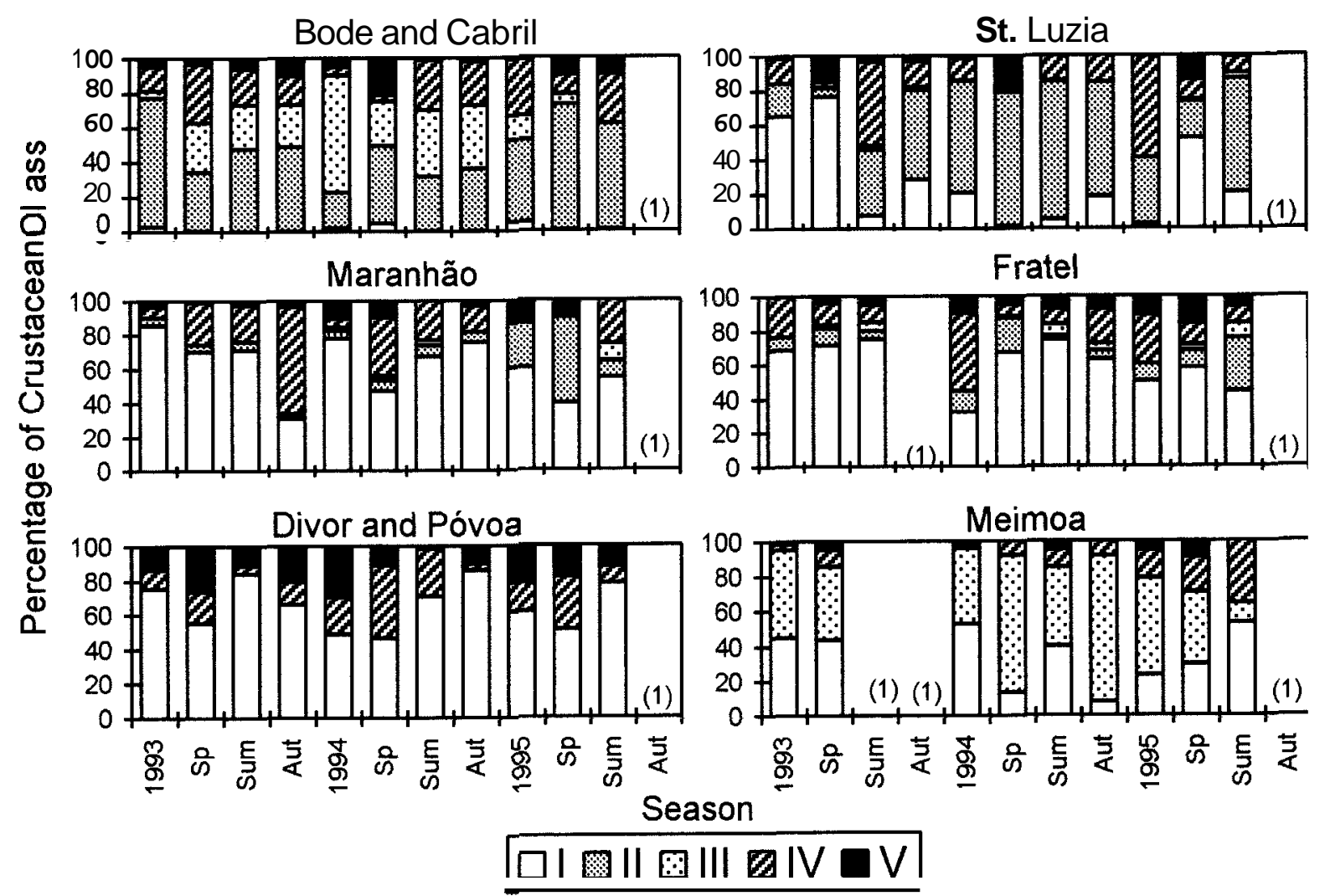

Figure 11. Proportion of each crustacean class in reservoirs where Class II was the dominant (C. Bode, Cabril, St. Luzia); where Class I dominated and Class II was represented (Maranhão, Fratel) or absent (Divor, Póvoa) and where Class III dominated (Meimoa). Proporción de cada clase de crustáceos en los embalses donde la Clase Il era dominance (C. Bode, Cabril, St. Luzia), en los que la Clase I dominaba y la Clase Il estaba representuda (Maranhão, Fratel) o ausente (Divor, Pdvoa) y donde la Clase II dominaba (Meimoa).

High temperatures, lack of rain and water drainage for human use could all have contributed for this increase in trophic state. This reservoir classification agrees with Marques \& Boavida (1997) although these authors in 1991, 1992 and 1993 classified Divor as mesotrophic (so as Cabril) and Fratel as eutrophic taking both chlorophyll and total phosphorus into consideration. However, their samples were mainly collected during summer (com. pers.) and the effect of low water level may have been of importance, especially in the case of Fratel located on Tagus River.

Divor was classified as one of the most eutrophic reservoirs which was confirmed by the highest rotifer density recorded. Karabin (1985) index was, however, inappropriate to ascribe trophic state to the other reservoirs where lower densities of rotifers were recorded. However, the large mesh size $(80 \mu \mathrm{m})$ of the net used to collect the specimens may have prevented the identification of some reservoirs (e.g. Póvoa) as eutrophic by Karabin's (1985) method. In late 70's Cabril, C. Bode and St. Luzia were considered oligotrophic (Cabeçadas et al., 1980; Monteiro, 1982; Oliveira 1982). However, Cabril and C. Bode in early 80's were considered as be approaching mesotrophy (Fernandes, 1985a,b). Belver and Fratel were considered mesotrophic although plankton was recognized as unstable because of river flow (Monteiro, 1977; Oliveira, 1977). Maranhão was considered to be at the edge of eutrophy while Divor and Póvoa were already eutrophic (Monteiro, 1984; Oliveira, 1984). When reservoirs were grouped according to species compo- 
sition at each season, groups followed the trend of TSI grouping. However, these results should always be analysed carefully since some communities may be under the influence of peculiar factors as seemed to be the case of Meimoa. The lack of diaptomids in this reservoir apparently was the factor responsible for the placement of this mesotrophic reservoir closer to the most eutrophic reservoirs in winter.

Acanthocyclops vernalis is generally associated with Copidodiaptomus steueri and Daphnia hyalina in Spanish reservoirs (Margalef et al., 1976). A similar association was found in the reservoirs studied although Acanthocyclops robustus and Copidodiaptomus numidicus replaced $A$. vernalis and $C$. steueri, respectively. Several authors (Cabeçadas et al., 1980; Oliveira, 1982; Monteiro, 1984, 1988; Fernandes, 1985a, b) have alternatively classified Copidodiaptomus species as steueri and numidicus and Acanthocyclops species as robustus and vernalis. Nevertheless, the calanoid and the cyclopoid have been reported to be associated. In clear water reservoirs, C. numidicus clearly dominated while A. robustus was represented by small populations or was replaced by Cyclops strenuus (Cabril and C. Bode) or Macrocyclops albidus (Meimoa and St. Luzia). Calanoids were thus favoured over cyclopoids probably as a result of edible phytoplankton scarcity (Soto \& Hurlbert, 1991a). Copidodiaptomus decreased in numbers in the more eutrophic reservoirs and was utterly replaced by large populations of $A$. robustus. The decline of calanoids has been frequently found in cases of eutrophication (e.g. Patalas 1972, Maier 1996). Under eutrophication processes, calanoids have been reported to be replaced both by cladocerans (Tonolli, 1962; MacNaught, 1975; Edmondson, 1977) and cyclopoid species (Adrian, 1997). The advantage of Daphnia over Eudiaptomus in eutrophic conditions was related by Muck \& Lampert (1980, $1984)$ to the ability of the cladoceran to increase their feeding rate to a higher level than the calanoid can. Calanoid development stages have lower food threshold concentration relatively to cyclopoids (Santer, 1994) and delays in the duration of the oviductal cycle of cyclopoids were
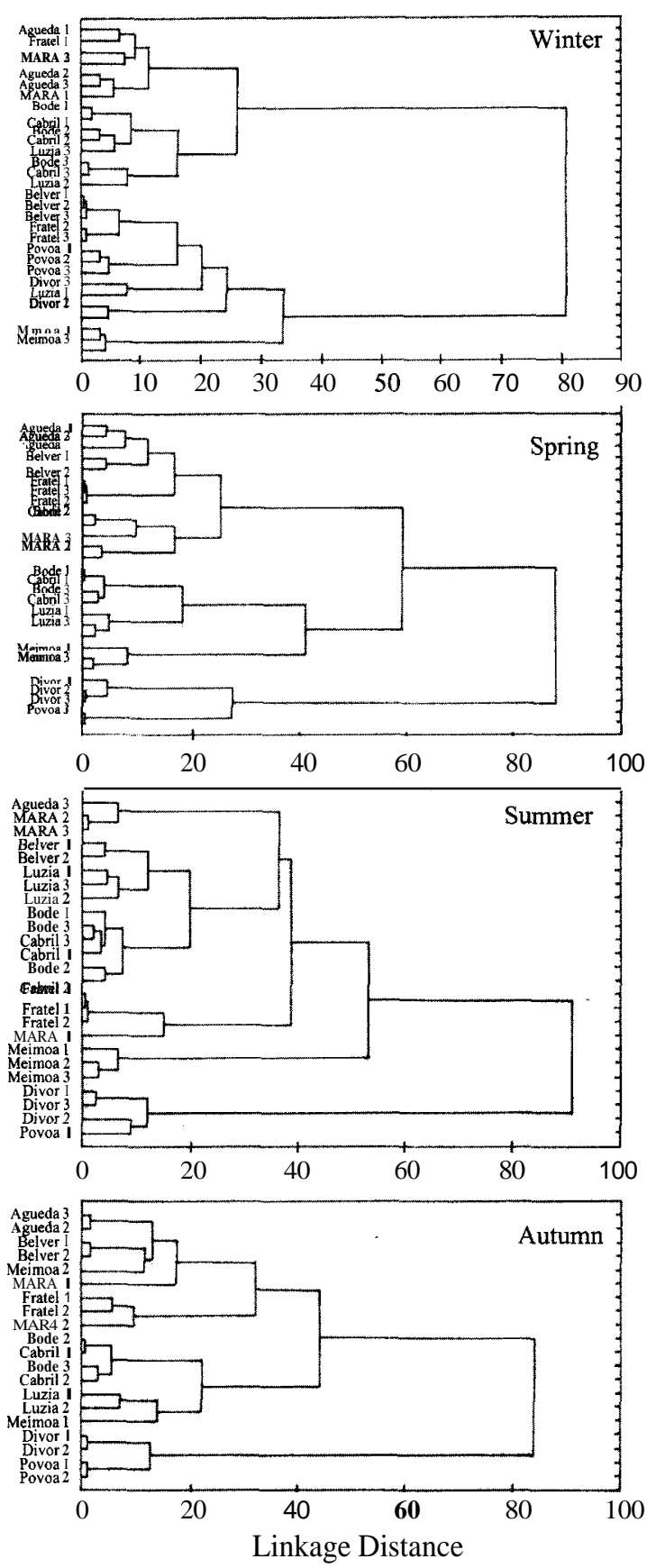

Figure 12. Dendrogram depicting group of reservoirs according to species densities at each season. MARA indicates Maranhão reservoir. 1, 2 and 3 indicate 1993, 1994 and 1995, respectively. Dendrograma mostrando los grupos de embalses de acuerdo con las densidades de especies en cada estación. MARA indica embalse de Maranhão. Los n'meros 1, 2 y 3 indicun rvspectivumente 1993, 1994 I' 1995. 
observed under strictly herbivorous conditions (Maier, 1989, 1992; Caramujo \& Boavida, 1999). In the studied reservoirs the higher proportion of calanoid to cyclopoid copepodid stages relatively to the equivalent proportion of naupliar stages suggested that cyclopoid populations were not being limited mainly by reproductive constraints but rather by the ability of their naupliar stages to develop successfully. These data corroborated the results of Soto \& Hurlbert (1991a,b) that ascribe an advantageous position to calanoid nauplii over cyclopoid nauplii under low feeding conditions. A. robustus was the only copepod species inhabiting the more eutrophic reservoirs (Divor and Póvoa) where it was usually accompanied by large populations of Bosmina longirostris. Since the abundance of the copepod showed a direct relationship with the increase in rotifers and CHLa, it is highly tempting to relate this species to eutrophication. A proliferation of A. robustus was previously associated with eutrophication in the bay of the Helsinkii sea area (Purasjoki \& Viljamaa, 1984) and in Lake Konstanz (Einsle, 1988). Maranhiio was emptied in 1991. After refilling, $\boldsymbol{A}$. robustus was the only copepod species present and $C$. numidicus only reappeared when the water transparency increased (Crispim, 1997). A. robustus is primarily an omnivorous species but may utilize algae which are suitable for egg production (Hopp et al. 1997). Under suitable feeding conditions, $A$. robustus had the highest reproductive output and adult longevity among four other cyclopoid species (Hopp et al. 1997). However, the situation was reversed when on algal diet. The amount of $\mathbf{A}$. robustus eggs in Divor was correlated to CHLa but this relation may be the indirect result of better feeding conditions to A. robustus prey (i.e. rotifers). In the reservoirs of Tagus River Basin the decrease of the proportion of calanoids to cyclopoids as well as an increase in $A$. robustus density was related to an increase in CHLa concentration.

The proportion of the genus Daphnia relative to the cladoceran community also decreased with eutrophication increase. Besides the change in abundance, the genus Daphnia was represented by different species in reservoirs at different tro- phic degrees. Large Daphnia species dominated in reservoirs with clearer water (more oligotrophic) and a shift towards small bodied species was observed in more eutrophic reservoirs with D. pawula and D. cuccullata only occurring in the most eutrophic reservoirs. This shift in size could not reflect only the presence of fish since in Maranhiio D. pawula was present when the fish population was low, after the drastic decrease through reservoir emptying. Furthermore, $D$. pulex was present in Fratel when fish was present in the reservoir (inquiries to fishermen). Adrian and Deneke (1996) also found a shift in warm springs towards the small bodied species ( $D$. galeata to D. cucullata) ascribed to the change in the food size spectra (Geller \& Müller 1981) due to an increase in winter temperatures. CHLa values should be regarded with caution since large cyanobacteria (i.e. over $40 \mu \mathrm{m}$ ) may not be considered edible by cladocerans (e.g. Daphnia, Adrian and Deneke, 1996). In Belver, Fratel, St. Agueda and in all southern reservoirs, blooms of cyanobacteria were observed. Filaments of cyanobacteria seriously disturb the filtering process in daphnids which are forced to clean their food groove (Burns, 1968; Gliwicz, 1980). Webster \& Peters (1978) and Gliwicz \& Lampert (1990) showed that the inhibitory effects of cyanobacteria depend on cladoceran body size, with large species being more affected than small species. Large amounts of phytoplankton allied to cyanobacteria presence seem to have favoured small daphnids and small cladocerans in eutrophic reservoirs. In feeding experiments Crispim (1997) found that D. pawula was unable to survive at low food level $\left(5 \cdot 10^{3}\right.$ cells $\left./ \mathrm{ml}\right)$ while $D$. hyalina (and Diaphanosoma) established large populations. However, under suitable feeding conditions $\left(5 \cdot 10^{4}\right.$ cells $\left./ \mathrm{ml}\right)$ D. parvula rapidly established a population larger than $D$. hyalina. The presence of D.pulex and its coexistence with D. hyalina is difficult to explain. In coexistence experiments Bengtsson (1986) found that the smallest species was excluded. However, it is accepted that it may be advantageous to be small when food is scarce and daphnids have to endure starvation (Lynch, 1979). It would be interesting 
to investigate the process underlying Daphnia interactions in Belver, Fratel and St. Agueda.

Classification of crustacean species according to the nature and way of collecting food raises problems because of the different food demands of the several development stages. This difference in food demand is even more acute in the case of raptorial copepods since naupliar and earlier copepodid stages are filter feeding herbivores. Although with limitations, especially in the case of the genus Daphnia, the display of the community according to the proportion of crustacean classes offers important information on community organization. Species composition of each class should, however, always be taken into consideration since carnivorous populations in oligotrophic reservoirs were mainly of Macrocyclops albidus while in eutrophic reservoirs carnivores were exclusively $\boldsymbol{A}$. robustus. Moreover, the presence of large amounts of cladocerans of class $\mathrm{V}$ may be misleading due to large amounts of D. parvula and D. cucullata in eutrophic reservoirs. Class IV may also be misleading due to the presence of large populations of Diaphanosoma and Ceriodaphnia in clear water reservoirs, which are replaced by Bosmina in more eutrophic reservoirs. Nevertheless, herbivorous calanoids dominated in more oligotrophic waters, while predator copepods dominated in more eutrophic waters. Non predaceous cyclopoids were an important zooplankton class, mainly at summer, in reservoirs with high proportion of diatoms in the phytoplankton. Green algae are poorly assimilated (Horn, 1981) because cyclopoids lack cellulase (Fryer, 1957). Cyclopoids may feed selectively on diatoms and assimilate them efficiently (Toth \& Zankai, 1985; Knisely \& Geller, 1986; Toth et al., 1987; Hansen \& Jeppesen, 1992). Development of $T$. dybowskii in the most oligotrophic reservoirs and the absence of $\mathrm{C}$. numidicus in a reservoir with high amounts of diatoms (Meimoa) should be investigated.

The proportion of calanoids to cyclopoids is an efficient method to collect information on trophic state of the reservoirs especially when accompanied by data on the abundance of A. robustus and Bosmina.

\section{ACKNOWLEDGEMENTS}

We would like to thank F. Bettencourt, C. Carvalho, M. C. Crispim, C. F. Baião, A. P. Abreu, R. Silva, J. Vieira and M. Carvalho whose valuable assistance allowed the collection of samples. This study was partially supported by doctoral grant BD-5358/95 awarded to M. J. Caramujo by Junta Nacional de Investigação Cientifica e Tecnológica (J.N.I.C.T.), Portugal.

\section{REFERENCES}

ADRIAN, R. 1997. Calanoid-cyclopoid interactions: evidence from an 11-year field study in a eutrophic lake. Freshwut. Biol., 38: 315-325.

ADRIAN, R. \& R. DENEKE. 1996. Possible impact of mild winters on zooplankton sucession in eutrophic lakes of the Atlantic European area. Freshwat. Biol., 36: 757-770.

ARMENGOL, J. 1978. Planktonic crustaceans of Spanish reservoirs. Oecologia Aquatica, 3: 3-96. (in Spanish).

ARMENGOL, J. 1980. Colonization of Spanish reservoirs by planktonic crustaceans and evolution of reservoir communities. Oecologiu Aquatica, 4: 4570. (in Spanish).

BENGTSSON, J. 1986. Life histories and interspecific competition between three Daphnia species in rockpools. J. Anim. Ecol., 66: 641-655.

BROOKS, J. L. \& S. I. DODSON. 1965. Predation, body size and the composition of plankton. Science, 150: 28-35.

BURNS, C. W. 1968. Direct observation of mechanisms regulating feeding behaviour of Daphnia in lake water. Int. Revue ges. Hydrobiol., 53: 83-100.

CABEÇADAS, M. G., M. H. CAVACO, M. T. MONTEIRO \& M. R. OLIVEIRA. 1980. Limnological study of Castelo do Bode Reservoir. Bol. Inst. Nac. Invest. Pescus, 4: 5-127. (in Portuguese)

CARAMUJO, M. J. \& M. J. BOAVIDA. 1998.Acanthocyclops robustus external morphology. How many morphs? Verh. int. Ver. Limnol., 26: 19041912.

CARAMUJO, M. J. \& M. J. BOAVIDA. 1999. Characteristics of the reproductive cycles and development times of Copidodiaptomus numidicus (Copepoda: Calanoida) and Acanthocyclops robustus (Copepoda: Cyclopoida). J. Plankton Res.: 1765-1778. 
CARLSON, R. E. 1977. A trophic state index for lakes. Linmol. Oceanogr, 22: 361-369.

CARPENTER S.R., T.M. FROST, J.F. KITCHELL \& T.K. KRATZ. 1993. Species dynamics and global environmental change: a perspective from ecosystem experiments. In: Biotic Interactions and Global Change P.M. Kareiva, J.G. Kingsolver \& R.B. Huey (eds.): 267-279. Sinauer Associates Inc. Sunderland, MA.

CRISPIM, M. C. 1997. Study of the impact of reservoir emptying on zooplunkton community in Maranhão Reservoir: Main biotic relationships controlling cladocerans. Ph. D. Thesis. University of Lisboa. 183 p. (in Portuguese)

DUSSART, B. H. \& C. H. FERNANDO. 1990. A review of the taxonomy of five Ontario genera of freshwater cyclopoid Copepoda (Crustacea). Can. J. Zool., 68: 2594-2604.

EDMONDSON, W. T., 1977. Lake Washington and the predictability of Limnological events. Jubilee Symposium on Lake Metabolism and Lake Management. University of Uppsala, August 22-27, 9 p.

EINSLE, U. 1988. The long-term dynamics of crustacean communities in Lake Constance (Obersee, 1962-1986). Schweiz. Z. Hydrol., 50: 136-165.

FERNANDES, M. J. 1985a. Study in defence of Castelo-do-Bode Reservoir. EPALDSEP (March). Lisboa. (in Portuguese)

FERNANDES, M. J. 1985b. Study in defence of Castelo-do-Bode Reservoir. Annex. EPALDSEP (November). Lisboa. (in Portuguese)

FLOSSNER, D. \& K. KRAUS. 1986. On the taxonomy of the Duphnia hyalina-galeata complex (Crustacea: Cladocera). Hydrobiologia, 137: 97-115.

FRYER, G. 1957. The food of some freshwater cyclopoid copepods and its ecological significance. J. Anim. Ecol., 26: 262-286.

GANNON, J. E. \& R. S. STEMBERGER. 1978 Zooplankton (especially crustaceans and rotifers) as indicators of water quality. Truns. Am. Micros. Soc., 97: 16-35.

GELLER W. \& H. MÜLLER 1981. The filtration apparatus of cladocera: filter mesh size and their implications on food selectivity. Oecologia, 49: 316-321.

GLIWICZ, Z. M. 1980. Filtering rates, food size selection and feeding rates in cladocerans another aspect of interspecific competition in filter-feeding zooplankton. In: Evolution and Ecology of zooplankton communities. W. C. Kerfoot (ed.): 282291. University Press of New England, Hanover.
GLIWICZ, Z. M. \& W. LAMPERT. 1990. Food thresholds in Daphnia species in the absence and presence of blue-green filaments. Ecology, 71: 691702.

GULATI, R. D. 1984. The zooplankton and its grazing as measures of trophy in the Loosdrecht Lakes. Verh. int. Ver. Limnol., 22: 863-867.

HANSEN, A.-M. \& E. JEPPESEN. 1992. Life cycle of Cyclops vicinus in relation to food availability, predation, diapause and temperature. J. Plankton Res., 14: 591-605.

HANSEN, A.M. \& B. SANTER. 1995. The influence of food resources on the development, survival and reproduction of the two cyclopoid copepods: $C y$ clops vicinus and Mesocyclops leuckarti (Claus). J. Plankton Res., 17: 631-646.

HOOP, U., G. MAIER \& R. BLEHER. 1997. Reproduction and adult longevity of five species of planktonic cyclopoid copepods reared on different diets: a comparative study. Freshwat. Biol., 38: 289-300.

HORN, W. 1981. Phytoplankton losses due to zooplankton grazing in a drinking water reservoir. Int. Revue Ges. Hydrobiol., 66: 787-810.

HURLBERT, S. H. \& M. S. MULLA. 1981. Impacts of mosquitofish (Gambusia affinis) predation on plankton communities. Hydrobiologia, 83: 125-151.

HUTCHINSON, G. E. 1967. Treatise on Limnology. Vol II. Introduction to the lake biology and limnoplankton. John Wiley. New York. 1115 p.

KARABIN, A. 1985. Pelagic zooplankton (Rotatoria and Crustacea) variation in the process of lake eutrophication. 1. Structural and quantitative features. Ekol. Pol., 33: 567-616.

KIEFER, F. 1978. Das Zooplankton der Binnengewasser. 2 Teil. E. Schweizerbart'sche Verlagsbuchhandlung (Nagele \& Obermiller), Stuttgart.

KNISELY, K. \& W. GELLER. 1986. Selective feeding of four zooplankton species on natural lake phytoplankton. Oecologiu, 69: 86-94.

LYNCH, M. 1979. Predation, competition and zooplankton community structure: an experimental study. Limnol. Oceunogr, 24: 253-272.

MACNAUGHT D. C. 1975. A hypothesis to explain the succession from calanoids to cladocerans during eutrophication. Verh. int. Ver. Lirnnol., 19:729731.

MAIER, G. 1989. The effect of temperature on the development time of eggs, naupliar and copepodid stages of five species of cyclopoid copepods. Hydrobiologia, 184: 79-88. 
MAIER, G. 1992. The reproductive biology of $C y$ clops vicinus. J. Plankton Res., 14: 127-135.

MAIER, G. 1996. Copepod communities in lakes of different trophic degree.Arch. Hydrobiol., 136:455-465.

MARGALEF, R. 1953. Crustaceans from Iberian freshwaters. In: Biología de las aguas continentales 10. Minist. Agricultura, Inst. Forestal de Investigaciones y Experiencias. Madrid. 243 pp. (in Spanish)

MARGALEF, R., D. PLANAS, J. ARMENGOL, A. VIDAL, N. PRAT, A. GUISET, J. TOJA \& M. ESTRADA. 1976. Limnology of Spanish Reservoirs. Vols. I and II. Dept. Ecologia Univ. Barcelona. $\mathrm{M}^{\circ}$ Obras Publicas. Madrid. (in Spanish)

MARQUES, R. T. \& M. J. BOAVIDA. 1997. Monitoring water quality in the Portuguese reservoirs of the River Tejo watershed. Verh. int. Ver. Limnol., 26: 740-744.

MATVEEVA, L. K. 1991. Can pelagic rotifers be used as indicators of lake trophic state? Verh. int. Ver. Limnol., 24: 2761-2763.

MONTEIRO, M. T. 1977. Study of the zooplankton community from Belver and Fratel reservoirs. In: Estudo Limnológico das Albufeirus de Belver $e$ Fratel: 45-58. Instituto Nacional de Investigação das Pescas. (in Portuguese)

MONTEIRO, M. T. 1982. Study of the zooplankton communities from Santa-Luzia, Cabril and Bouçã reservoirs. Bol. Inst. Nac. Invest. Pescas, 8: 27-39. (in Portuguese)

MONTEIRO, M. T. 1984. Study of the zooplankton communities from reservoirs south to river Tagus. Bol. Inst. Nac. Invest. Pescas., 11: 28-43. (in Portuguese)

MONTEIRO, M. T. 1988. Zooplanktonic communities from Southern Portuguese Reservoirs. Ph. D. Thesis. Inst. Nac. Invest. Pescas. Lisboa. 258 pp. (inPortuguese)

MUCK, P. \& W. LAMPERT. 1980. Feeding of freshwater filter-feeders at very low food concentrations: poor evidence for "threshold feeding" and "optimal feeding" in Daphnia longispina and Eudiaptomus gracilis. J. Plankton Res., 2: 367-379.

MUCK, P. \& W. LAMPERT. 1984. An experimental study on the importance of food conditions for the relative abundance of calanoid copepods and cladocerans. Archiv. fur Hydrobiologie. Supplement 66: 157-179.

NOGRADY, T. (ed) 1993. Rotifera. Guides to the identification of the microinvertebrates of the continental waters of the world. SPB Academic Publishing, The Hague, The Netherlands.
OLIVEIRA, M. R. 1977. Phytoplankton from Fratel and Belver reservoirs. In: Estudo Limnoldgico das Albufeiras de Belver e Fratel : 39-45. Instituto Nacional de Investigação e Pescas. (in Portuguese)

OLIVEIRA, M. R. 1982. Phytoplankton specific composition, density and seasonal dynamics in Bouçã, Cabril, Santa-Luzia and Pracana reservoirs. Boletim Nacional de Investigação das Pescas, 8: 5-25. (in Portuguese)

OLIVEIRA, M. R. 1984. Contribution to the study of phytoplankton communities in reservoirs located south to river Tagus. Boletim Nacional de Investigação e Pescas, 8: 5-25. (in Portuguese)

PATALAS K. 1972. Crustacean plankton and the eutrophication of St. Laurence Great Lakes. J. Fish. Res. Bd Can., 29: 1451-1462.

PEJLER, B. 1983. Zooplanktonic indicators of trophy and their food. Hydrobiologia, 101: 101-114.

PURASJOKI, K. \& H. VILJAMAA. 1984. Acanthocyclops robustus (Copepoda, Cyclopoida) in plankton of the Helsinki sea area, and a morphological comparison between $A$. robustus and A. vernalis. Finnish Marine Res., 250: 33-44.

RICE, W. R. 1989. Analysing tables of statistical tests. Evolution, 34: 223-225.

SANTER, B. 1994. Influences of food type and concentration on the development of Eudiaptomus gracilis and implications for interactions between calanoid and cyclopoid copepods. Arch. Hydrobiol., 131: 141-159.

SCHINDLER, D. W. 1987. Detecting ecosystem responses to anthropogenic stress. Can. J. Fish. Aq. Sci., 44: 6-25.

SOTO, D. \& S. H. HURLBERT. 1991a. Short-term experiments on calanoid-cyclopoid-phytoplankton interactions. Hydrobiologia, 215: 83-110.

SOTO, D. \& S. H. HURLBERT. 1991b. Long-term experiments on calanoid-cyclopoid interactions. Ecol. Monographs, 61: 245-265.

STANDARD METHODS. 1992. Standard Methods for the examination of water and waste water:American Public Health Association. 18th Ed. Washington D.C., U.S.A.

SCHWENK, K., A. SAND, M. BOERSMA, M. BREHM, E. MADER, D. OFFERHAUS \& P. SPAAK. 1998. Genetic markers, genealogies and biogeographic pattern in the cladocera. Aquat. Ecol., 32: 37-51.

TOJA, J. 1980. Limnology of La Minilla reservoir during 1976. II. Zooplankton distribution. Oecologia Aquntica, 4: 89-110. (in Spanish). 
TONOLLI, V. 1962. The present situation of planktonic populations in lake Maggiori. Mem. Ist. Ital. Idrobiol., 15: 81-134. (in Italian)

TOTH, L. G. \& N. P. ZANKAI. 1985. Feeding of Cyclops vicinus (Uljanin) (Copepoda: Cyclopoida) in Lake Balaton on the basis of gut contend analyses. Hydrobiologia, 122: 251-260.
TOTH, L. G., N. P. ZANKAI \& O. M. MESSNER. 1987. Algae consumption of four dominant planktonic crustaceans in lake Balaton (Hungary). $\mathrm{Hy}$ drobiologia, 122: 323-332.

WEBSTER, K. E. \& R. H. PETERS. 1978. Some sizedependent inhibitions of larger cladoceran filterers in filamentous suspensions. Limnol. Oceanogs, 23: 1238-1245. 